\title{
Occurrence of antibiotic resistance and integronase genes in Taihu Lake
}

\author{
Jian Wang, Haiqing Pu, Lin Ye, Liangyan Chen ${ }^{*}$ and Xuxiang Zhang* \\ State Key Laboratory of Pollution Control and Resource Reuse, School of the Environment, Nanjing University, Nan- \\ jing, People's Republic of China
}

\begin{abstract}
Antibiotic resistance genes (ARGs), a potential threat to the health of humans and animals, have been widely detected in various environments. However, not much information about ARGs in freshwater lakes have been recorded. In this study, we investigated the occurrence of 17 kinds of ARGs and three types of integronase genes in Taihu Lake (China), an important drinking water source for local residents. Fecal coliforms were also isolated from the water and sediments for antimicrobial susceptibility tests and related ARGs detection. Results showed that tetracycline resistance gene tetC, sulfanilamide resistance genes sul1 and sul2, and class 1 integronase gene int 1 were present in all water and sediment samples. TetG was present in all water samples but was mainly distributed in sediment samples from the northern region of Taihu Lake. $\beta$-Lactam resistance gene bla $a_{\text {OXA-1 }}$ was present in all water samples but was absent in the sediment samples. Tet $\mathrm{M}$ and tetO were found present in water and sediment samples from the western area of the lake. Remarkably, 95\% of isolated fecal coliforms were resistant to trimethoprim and multi-drug resistant isolates were also observed. Sul1 and tetC genes were found to be carried by isolates resistant to corresponding antibiotics. This study provided baseline information about the occurrence of ARGs and integronase genes in Taihu Lake and the results may extend our knowledge about antibiotic resistance of microbial communities in the lake.
\end{abstract}

Keywords: antibiotic resistance genes, class 1 integrons, fecal coliforms, Taihu Lake, water environment

*Correspondence to: Liangyan Chen, Xuxiang Zhang; State Key Laboratory of Pollution Control and Resource Reuse, School of the Environment, Nanjing University, 163 Xianlin Road, Nanjing 210023, China; Email: chenly@nju.edu.cn, zhangxx@nju.edu.cn

Received: October 24, 2015; Accepted: January 20, 2016; Published Online: April 8, 2016

Citation: Wang J, Pu H, Ye L, et al. 2016. Occurrence of antibiotic resistance and integronase genes in Taihu Lake. Applied Envi-ronmental Biotechnology, vol.1(1): 71-80. http://dx.doi.org/10.26789/AEB.2016.01.006.

\section{Introduction}

W ithin the past 70 years, antibiotics have been increasingly developed and applied to treat diseases and promote animal production after penicillin was first developed. The misuse of antibiotics has resulted in widespread antibiotic resistant bacteria (ARB) and resistance genes (ARGs) in the aquatic environment ${ }^{[1,2]}$. ARGs have the ability to transfer from the host bacteria to other species through conjunction, transduction, or transformation ${ }^{[3]}$, which in turn changes the structure and activity of microbial communities especially in the presence of antibiotics ${ }^{[4]}$.
Unremarkably, the acquisition of ARGs in pathogens leads to drug failure, posing serious potential health threats to humans and animals ${ }^{[5]}$. Among various kinds of antibiotics, tetracycline, sulfanilamide, and $\beta$-lactam are the most frequently used in animal production and disease treatment ${ }^{[6]}$. To date, more than 38 tetracycline resistance genes ${ }^{[7]}$, 20 sulfanilamide resistance genes $^{[8]}$, and $200 \beta$-lactam resistance genes ${ }^{[9]}$ have been detected in the environment. Moreover, integrons carrying various ARGs have also been discovered in the environment ${ }^{[10]}$. These integrons are endogenous DNA sequences that can incorporate exogenous ARGs into their gene cassettes which play

Occurrence of antibiotic resistance and integronase genes in Taihu Lake. (C) 2016 Jian Wang, et al. This is an Open Access article distributed under the terms of the Creative Commons Attribution-NonCommercial 4.0 International License (http://creativecommons.org/licenses/by- nc/4.0/), permitting all non-commercial use, distribution, and reproduction in any medium, provided the original work is properly cited. 
important roles in horizontal transfer of ARGs ${ }^{[11]}$.

As the third largest freshwater lake in China, Taihu Lake is an important drinking water source for millions of local residents. However, the lake has been suffering from serious water pollution in the past 30 years. Previous studies focused on the notorious algal bloom annually happening in the lake. Toxic microcystin $^{[12]}$, various organic pollutants ${ }^{[13]}$, and heavy metals ${ }^{[14]}$ have also been found present in the lake water. However, less attention has been paid to the occurrence of ARGs in Taihu Lake which can also pose great health threats to humans.

Amounts of treated or untreated domestic sewage is discharged into Taihu Lake through over 20 river branches ${ }^{[15]}$. Sewage is considered as an important environmental reservoir for a variety of ARB and $\mathrm{ARGs}^{[16]}$. Moreover, rapid development of animal breeding and aquaculture in the region may contribute to the emergence of ARB and ARGs in the lake ${ }^{[17]}$. Previous studies have revealed that tetracycline resistance genes tet $\mathrm{A}$ and tet $\mathrm{C}$ are widely distributed in Meiliang Bay of the lake ${ }^{[1]}$ and Escherichia coli isolates from the lake's water are highly resistant to streptomycin, tetracycline and ampicillin ${ }^{[18]}$. However, a comprehensive study has not been conducted to investigate the occurrence of the ARB and ARGs in the lake water.

In this study, the occurrence of 17 kinds of ARGs (encoding resistance to tetracycline, sulfanilamide or $\beta$-lactam) and three types of integronase genes in Taihu Lake water and sediments were investigated using polymerase chain reactions (PCR). Fecal coliforms were also isolated from the lake water for antimicrobial tests and related ARGs detection. Results may extend our knowledge about antibiotic resistance of microbial communities in lakes undergoing disturbance from human activities.

\section{Materials and Methods}

\subsection{Sample Collection}

Water and sediments were sampled from 23 locations in Taihu Lake (Figure 1), including three drinking water source stations for the surrounding cities (Sites N7, N10, and S7). Water samples (1000 mL each) were collected in sterilized bottles from the 23 selected sites at a depth of $50 \mathrm{~cm}$ below the water surface in April 2012. Soft sediment samples (around 100 g each) were collected in sterilized bags using bottom sampler from 19 of the 23 sites (the bottom sampler was unable to collect samples from hard solid bottoms at sites N6, N11, N12, and S9), simultaneously. Water and sediment samples were kept on ice and transported to the lab within 6 hrs.

\subsection{DNA Extraction}

For DNA extraction, water samples were filtered onto cellulose ester filters (pore size $0.45 \mu \mathrm{m}$, Millipore, USA) until the filter gets clogged. After filtration, filters were cut into pieces immediately for total DNA extraction using FastDNA Spin Kit for Soil (MP Biomedicals, USA). Similarly, the kit was also used for total DNA extraction from the sediments (500 mg). All DNA extractions were performed strictly following the manufacturer's recommended protocol (MP Biomedicals, USA). Purified DNA was stored in $-20^{\circ} \mathrm{C}$ until further use.

\subsection{Isolation and Identification of Fecal Coliforms}

Each of the water samples $(5 \mathrm{~mL})$ from the different sites was diluted with $45 \mathrm{~mL}$ sterile saline solution $(0.85 \% \mathrm{NaCl})$. Each sediment sample (5 g) was also mixed with $45 \mathrm{~mL}$ sterile saline solution $(0.85 \% \mathrm{NaCl})$ and vibrated at a speed of $200 \mathrm{rpm} / \mathrm{min}$ at $28^{\circ} \mathrm{C}$. After vibrating for $30 \mathrm{~min}, 1 \mathrm{~mL}$ of the sediment-water mixture was diluted with $45 \mathrm{~mL}$ sterile saline solution $(0.85 \% \mathrm{NaCl})$ again. The diluted water and sediment samples were filtrated through the cellulose membranes (pore size $0.45 \mu \mathrm{m}$, Millipore, USA). The obtained membranes were stuck onto m-FC agar for fecal coliform incubation following the methods applied by Niemi et al. ${ }^{[19]}$. Sterile saline solution $(45 \mathrm{~mL})$ was used as a negative control. All the presumed fecal coliforms were further purified and identified by applying the analytical profile index (API) method from Adicon Clinical Laboratory (Nanjing, China). Total DNA was extracted from each of the fecal coliforms using the boiling method ${ }^{[20]}$.

\subsection{Antimicrobial Susceptibility Test}

Antibiotic resistance of the fecal coliforms was determined using the Kirby-Bauer disk diffusion method at Adicon Clinical Laboratory (Certification: No. CNAS MT0061) for antimicrobial susceptibility tests. Resistance to 7 commonly used antibiotics including tetracycline, ampicillin, minocycline, trimethoprim, streptomycin, gentamycin, and ciprofloxacin were tested in this study. Each bacterial isolate was classified as susceptible (S), intermediate (M), and resistant (R) to antibiotics. 


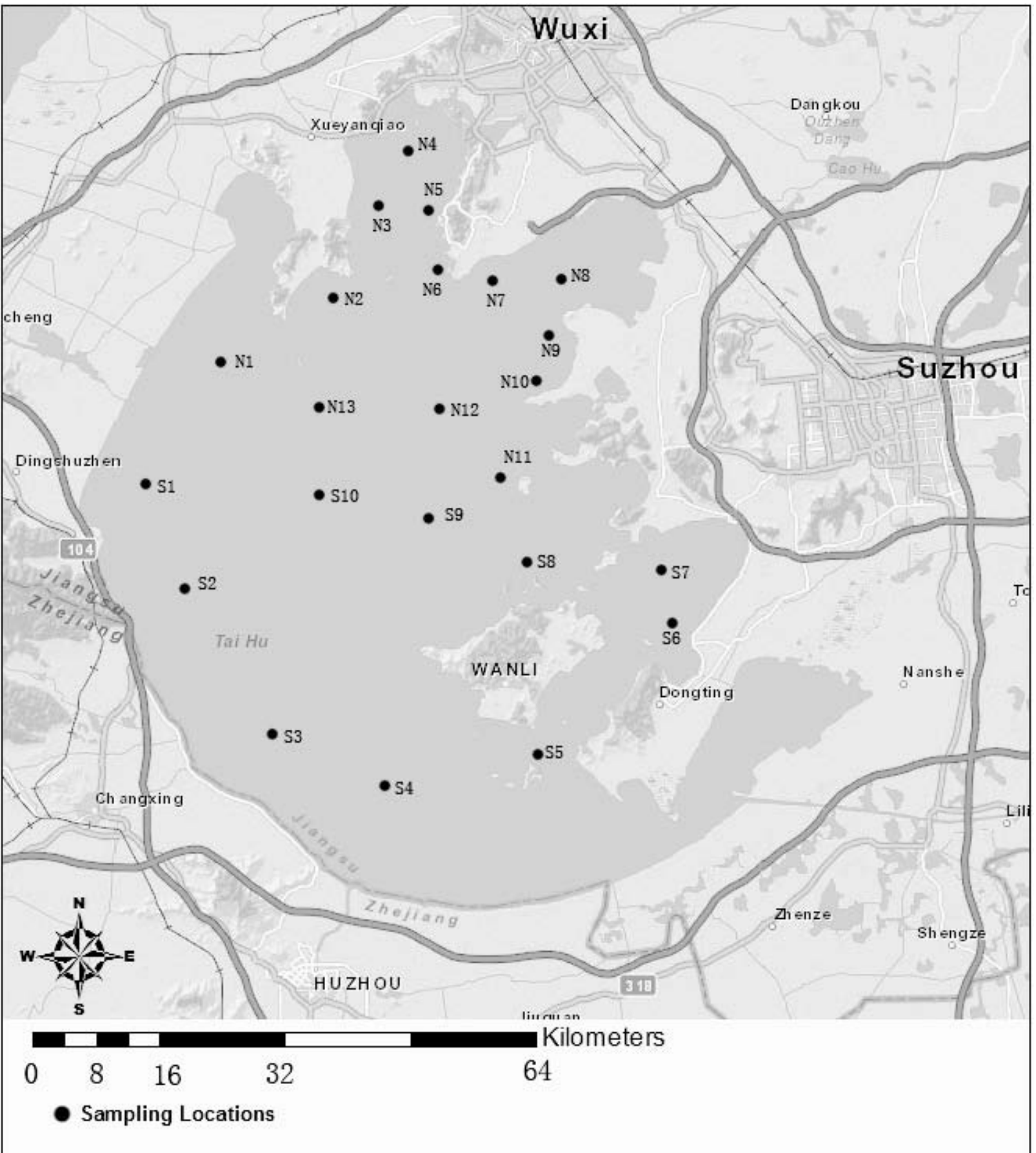

Figure 1. Sampling locations in Taihu Lake. Water and sediments were sampled from 23 locations in Taihu Lake, including three drinking water source stations for the surrounding cities (Sites N7, N10, and S7).

\subsection{Detection of ARGs and Integronases Genes}

We utilized the PCR technique to detect 17 kinds of ARGs and three types of integronase genes in each sample. Primer sequences used for PCR amplification of ARGs and integronase genes were listed in Table 1. The PCR system $(30 \mu \mathrm{L})$ contained $15 \mu \mathrm{L}$ of $2 \times$ EasyTaq PCR Supermix (TransGen Biotech, China), $1 \mu \mathrm{L}$ of each primer $(0.3 \mu \mathrm{M}), 2 \mu \mathrm{L}$ of template DNA, and $11 \mu \mathrm{L}$ of $\mathrm{ddH}_{2} \mathrm{O}$. PCR was initiated by incubating the reaction mixture at $94^{\circ} \mathrm{C}$ for $3 \mathrm{~min}$, followed by 30 cycles of $30 \mathrm{~s}$ at $94^{\circ} \mathrm{C}, 30 \mathrm{~s}$ at the annealing temperature (Table 1), and $1 \mathrm{~min}$ at $72^{\circ} \mathrm{C}$ for extension. The reaction was terminated after a final extension step for 7 min. Blank control ( $\mathrm{ddH}_{2} \mathrm{O}$ instead of template DNA) 
Table 1. Primers used to detect ARGs and integronase genes

\begin{tabular}{|c|c|c|c|c|c|}
\hline Gene & Primer pair ${ }^{\mathrm{a}}$ & Sequences (5’-3’) & Annealing temp $\left({ }^{\circ} \mathrm{C}\right)$ & Amplicon size (bp) & Reference \\
\hline \multirow{2}{*}{ tetA } & tetA-F & GCTACATCCTGCTTGCСТTC & \multirow{2}{*}{55} & \multirow{2}{*}{210} & \multirow{2}{*}[43]{} \\
\hline & tetA-R & CATAGATCGCCGTGAAGAGG & & & \\
\hline \multirow{2}{*}{ tetB } & tetB-F & TTGGTTAGGGGCAAGTTTTG & \multirow{2}{*}{55} & \multirow{2}{*}{659} & \multirow{2}{*}[43]{} \\
\hline & tetB-R & GTAATGGGCCAATAACACCG & & & \\
\hline \multirow{2}{*}{ tetC } & tetC-F & CTTGAGAGCCTTCAACCCAG & \multirow{2}{*}{55} & \multirow{2}{*}{418} & \multirow{2}{*}[43]{} \\
\hline & tetC-R & ATGGTCGTCATCTACCTGCC & & & \\
\hline \multirow{2}{*}{ tetD } & tetD-F & AAACCATTACGGCATTCTGC & \multirow{2}{*}{55} & \multirow{2}{*}{787} & \multirow{2}{*}[43]{} \\
\hline & tetD-R & GACCGGATACACCATCCATC & & & \\
\hline \multirow{2}{*}{ tet $\mathrm{G}$} & tetG-F & CAGCTTTCGGATTCTTACGG & \multirow{2}{*}{55} & \multirow{2}{*}{844} & \multirow{2}{*}[43]{} \\
\hline & tetG-R & GATTGGTGAGGCTCGTTAGC & & & \\
\hline \multirow{2}{*}{ tet $\mathrm{M}$} & tet $\mathrm{M}-\mathrm{F}$ & GTGGACAAAGGTACAACGAG & \multirow{2}{*}{55} & \multirow{2}{*}{406} & \multirow{2}{*}[43]{} \\
\hline & tet $\mathrm{M}-\mathrm{R}$ & CGGTAAAGTTCGTCACACAC & & & \\
\hline \multirow{2}{*}{ tetO } & tetO-F & AACTTAGGCATTCTGGCTCAC & \multirow{2}{*}{55} & 515 & [43] \\
\hline & tetO-R & TCCСАCTGTTCСАTATCGTCA & & ה & {$[40]$} \\
\hline teto & tetQ-F & TTATACTTCCTCCGGCATCG & 55 & 004 & [12] \\
\hline tetle & tetQ-R & ATCGGTTCGAGAATGTCCAC & 35 & 504 & $[4]]$ \\
\hline sul1 & sul1-F & CGGCGTGGGCTACCTGAACG & 55 & 133 & {$[44]$} \\
\hline & sul1-R & GCCGATCGCGTGAAGTTCCG & & & \\
\hline sull & sul2-F & TCCGGTGGAGGCCGGTATCTGG & 608 & 101 & [45] \\
\hline sutr & sul2-R & CGGGAATGCCATCTGCCTTGAG & 00.0 & 131 & $[4]]$ \\
\hline sul3 & sul3-F & TCCGTTCAGCGAATTGGTGCAG & 60 & 128 & {$[45]$} \\
\hline 年 & sul3-R & TTCGTTCACGCCTTACACCAGC & 00 & $1<0$ & {$[4]$} \\
\hline sulA & sulA-F & TCTTGAGCAAGCACTCCAGCAG & 60 & 299 & [45] \\
\hline उपtत & sulA-R & TCCAGCCTTAGCAACCACATGG & 00 & 205 & {$[40]$} \\
\hline$a m n C$ & ampC-F & ССТCTTGCTCСАCATTTGCT & 58 & 189 & {$[46]$} \\
\hline & ampC-R & ACAACGTTTGCTGTGTGACG & & & \\
\hline$b) a_{\text {тго }}$ & $b l a_{\mathrm{TEM}}-\mathrm{F}$ & ATAAAATTCTTGAAGACGAAA & 56 & 1086 & [25] \\
\hline DIUTEM & $b l a_{\mathrm{TEM}}-\mathrm{R}$ & GACAGTTACCAATGCTTAATC & 50 & 1000 & {$[\angle J]$} \\
\hline bla $a_{\text {Сuv }}$ & $b l a_{\mathrm{SHV}}-\mathrm{F}$ & GGGTTATTCTTATTTGTCGC & 58 & 567 & [25] \\
\hline DIU & $b l a_{\mathrm{SHV}}-\mathrm{R}$ & TTAGCGTTGCCAGTGCTC & & & \\
\hline$b b a_{\text {Стх }}$ & $b l a_{\mathrm{CTX}-\mathrm{M}}-\mathrm{F}$ & CGCTTTGCGATGTGCAG & 54 & 550 & [25] \\
\hline${ }_{11} \mathrm{CTX-M}$ & $b l a_{\mathrm{CTX}-\mathrm{M}}-\mathrm{R}$ & ACCGCGATATCGTTGGT & 47 & (500 & {$[20]$} \\
\hline$b l a_{\mathrm{OX}}$ & $b l a_{\mathrm{OXA}-1}-\mathrm{F}$ & ACACAATACATATCAACTTCGC & 56 & 885 & [25] \\
\hline TIU & $b l a_{\mathrm{OXA}-1}-\mathrm{R}$ & AGTGTGTTTAGAATGGTGATC & & & \\
\hline int1 & int I -F & ACGAGCGCAAGGTTTCGGT & 52 & 565 & [25] \\
\hline . & int I - R & GAAAGGTCTGGTCATACATG & $J 2$ & (50J & {$[20]$} \\
\hline int 2 & int II -F & GTGCAACGCATTTTGCAGG & 52 & 403 & ] \\
\hline . & int II -R & CAACGGAGTCATGCAGATG & di & 403 & {$[\angle 2]$} \\
\hline int 3 & intIII-F & CATTTGTGTTGTGGACGGC & $5 ?$ & 717 & [25] \\
\hline Tis & intIII-R & GACAGATACGTGTTTGGCAA & J2 & 年 & \\
\hline
\end{tabular}

\footnotetext{
${ }^{\mathrm{a}} \mathrm{F}$, forward; R, reverse
}

was included in all the PCRs. We performed agarose gel electrophoresis to detect target PCR products. Furthermore, PCR positive products were randomly selected and purified using QIAquick PCR purification kit for Sanger sequencing (BGI, China). The obtained sequences were subjected to BLAST against 
NCBI Nuclease Database to confirm the target genes. All sequences have been deposited in GenBank under accession numbers (Table 2).

Table 2. BLAST results of PCR-positive isolates. Results were obtained by comparing the sequence results of PCR-positive products with target gene sequences in the NCBI Nuclease Database

\begin{tabular}{cccc}
\hline \multirow{2}{*}{ Target genes } & Sequence results & \multicolumn{2}{c}{ BLAST results } \\
\cline { 3 - 4 } & & Accession No. & Similarity (\%) \\
\hline tetO & Successful & GQ240298.1 & $99 \%$ \\
tetM & Successful & JN846698.1 & $98 \%$ \\
tetG & Successful & AF133140.1 & $99 \%$ \\
tetC & Successful & EU751610.1 & $99 \%$ \\
sul2 & Successful & HQ441169.1 & $99 \%$ \\
sul1 & Successful & FJ711652.1 & $100 \%$ \\
int1 & Successful & JQ407409.1 & $99 \%$ \\
bla $_{\text {OXA-1 }}$ & Successful & GQ896560.1 & $99 \%$ \\
\hline
\end{tabular}

\subsection{Statistical analyses}

Microsoft Office Excel 2007 was used to analyze the occurrence of ARGs and integronase genes in both water and sediment samples.

\section{Results}

\subsection{ARGs and Integrons in Taihu Lake}

Among the 17 kinds of ARGs tested in this study, tetracycline resistance genes tet $\mathrm{C}$, and sulfanilamide resistance genes sul1 and sul2 were found in all 42 locations (23 water samples and 19 sediment samples) (Figure 2, Table 3). In the water samples, tetM was found at sites S2, S3, and S4, while tetO was found at sites N1, S3, and S4. Both of these two genes were mainly detected in the western region of Taihu Lake. $\beta$-Lactam resistance gene bla $a_{\text {OXA-1 }}$ was present in all water samples but was undetected in each of the sediment samples. TetG was present in all water samples but was only detectable in sediments of six sites (N1, N2, N3, N4, N5, and N8). TetM was found in the sediments of five sites (N1, N3, N4, N5, and N7). Both tet $\mathrm{G}$ and tet $\mathrm{M}$ were mainly distributed in the sediments of the northern region of Taihu Lake. The other 10 kinds of ARGs (tet $\mathrm{A}$, tet $\mathrm{B}, \operatorname{tet} \mathrm{D}$, tetQ, sul3, sulA, ampC, $b l a_{\mathrm{TEM}}, b l a_{\mathrm{SHV}}$, and $\left.b l a_{\mathrm{CTX}-\mathrm{M}}\right)$ were absent in both water and sediment samples. Class 1 integrons were present in all water and sediment samples, while classes 2 and 3 integrons were not detected in Taihu Lake.

\subsection{Antimicrobial Susceptibility of Fecal Coliforms}

A total of 82 presumed fecal coliform strains were isolated from water samples and 20 were identified as fecal coliforms via the ABI test. Antibiotic susceptibility analysis was conducted for all the fecal coliform isolates. Figure 3 showed resistance frequencies of the 7 tested antibiotics for all 20 strains. Most of the isolated fecal coliforms (95\%) were found resistant to trimethoprim. The resistance frequency of ampicillin, gentamycin, streptomycin, and ciprofloxacin was $20 \%$ (4 isolates), 10\% (2 isolates), 5\% (1 isolate), and 5\% (1 isolate), respectively. One isolate $(5 \%)$ had intermediate resistance to minocycline (excluded in Figure 3) but no isolate was found resistant to tetracycline. Remarkably, 5 isolates were found to be multi-resistant (resistant to at least 2 kinds of antibiotics) and one isolate was even resistant to 6 kinds of tested antibiotics.

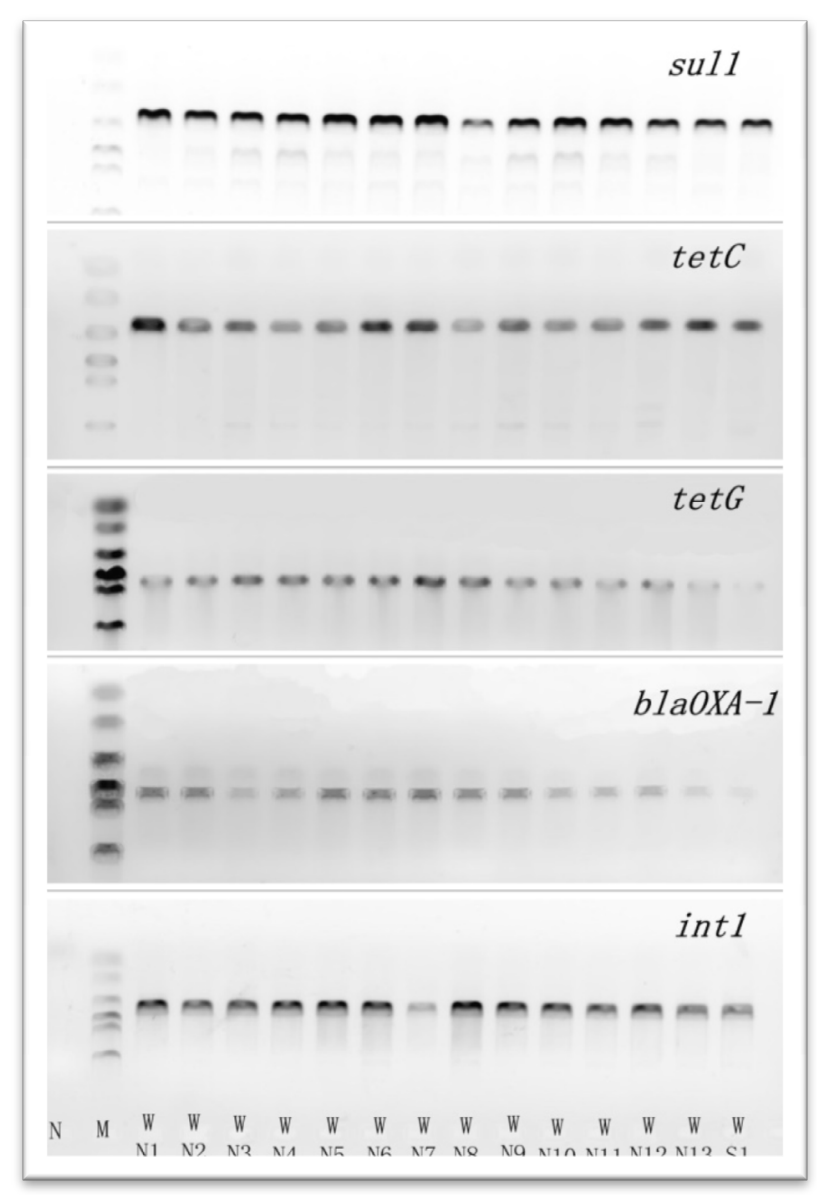

Figure 2. Occurrence patterns of sul1, tetC, tet $\mathrm{G}$, bla $a_{\mathrm{OXA}-1}$, and int1 genes in water samples analyzed via PCR product electrophoreses. N: blank control with sterilized $\mathrm{ddH}_{2} \mathrm{O}$ used as PCR template; M: DNA Marker (DL2000); W: water. 
Table 3. Occurrence of ARGs and integronase genes in water and sediment samples

\begin{tabular}{|c|c|c|c|c|c|c|c|c|c|c|c|c|c|c|c|c|c|c|c|c|}
\hline \multirow{2}{*}{ Sample type - } & \multicolumn{20}{|c|}{$\%$ of detection } \\
\hline & tetA & tet $\mathrm{B}$ & tet $\mathrm{C}$ & tetD & tet $\mathrm{G}$ & tet $\mathrm{M}$ & tetO & tetQ & sul1 & sul2 & sul3 & sulA & ampC & $b l a_{\mathrm{TEM}}$ & $b l a_{\mathrm{SHV}}$ & bla $_{C T X-M}$ & bla $_{O X A-1}$ & int1 & int2 & int3 \\
\hline Water & 0 & 0 & 100 & 0 & 100 & 13.04 & 13.04 & 0 & 100 & 100 & 0 & 0 & 0 & 0 & 0 & 0 & 100 & 100 & 0 & 0 \\
\hline Sediment & 0 & 0 & 100 & 0 & 31.58 & 26.32 & 0 & 0 & 100 & 100 & 0 & 0 & 0 & 0 & 0 & 0 & 0 & 100 & 0 & 0 \\
\hline
\end{tabular}

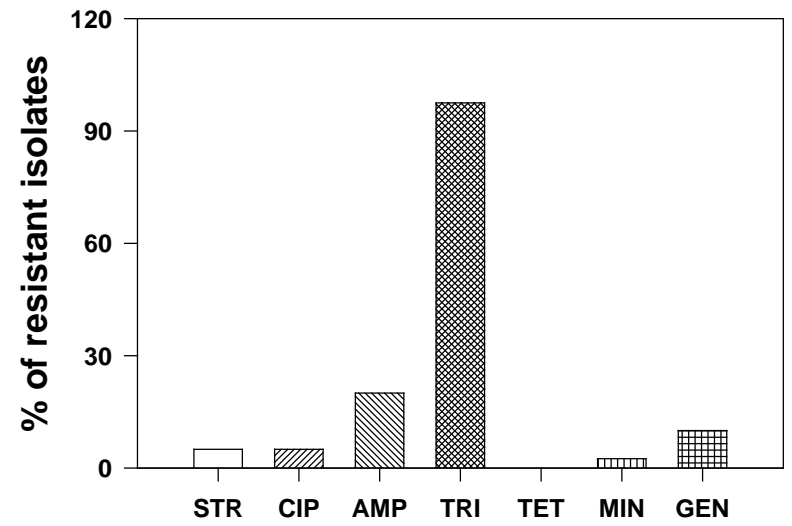

Figure 3. Frequencies of antibiotic resistance to the fecal coliforms $(n=20)$ in water and sediment samples in Taihu Lake. STR: streptomycin; CIP: ciprofloxacin; AMP: ampicillin; TRI: trimethoprim; TET: tetracycline; MIN: minocycline; GEN: gentamycin.

\subsection{ARGs and Class 1 Integrons in Fecal Coliforms}

We conducted PCRs to detect sul1 and sul2 in the bacterial isolates resistant to trimethoprim, $b l a_{\text {OXA- } 1}$ in the isolates resistant to ampicillin, and tetC and tet $\mathrm{G}$ in the isolates resistant to minocycline. As shown in Table 4, among the 20 trimethoprim resistant isolates, 8 were positive for sul1. The minocycline resistant isolate was found to carry tetC. Additionally, all 20 isolates were subjected to class 1 integronase gene int 1 detection, in which it was present in 2 isolates. However, sul2, bla $a_{\mathrm{OXA}-1}$, and tet $\mathrm{G}$ were undetected in the corresponding antibiotic resistant bacterial isolates.
Additionally, no isolate was found to host multiple ARGs (more than 2 kinds of ARGs) in this study.

\section{Discussion}

Currently, tetracycline resistance genes have been widely selected as an indicator to evaluate ARGs contamination $^{[21-23]}$. Among the four kinds of tetracycline resistance genes (tet $\mathrm{C}$, tet $\mathrm{G}$, tet $\mathrm{M}$, and tet $\mathrm{O}$ ) tested in this study, tetC was detected in all sampling sites (both water and sediment) and tet $\mathrm{G}$ was also detected in all water samples which was consistent with previous studies $^{[1,22,24-26]}$. Therefore, tet $\mathrm{C}$ and tet $\mathrm{G}$ may appear as the dominant tetracycline resistance gene types in Taihu Lake. Additionally, tet $\mathrm{G}$ were mainly present in the sediments of the northern parts of the lake (mainly in Meiliang Bay and Gonghu Bay), and tet $\mathrm{M}$ and tet $\mathrm{O}$ were mainly distributed in the western region. This was similar to the distribution pattern of organic pollutants and heavy metals in Taihu Lake which was presumably due to the comparatively greater impacts of anthropogenic activities in the northern and western regions $^{[14,27]}$.

Four sulfanilamide resistance genes (sul1, sul2, sul3, and sulA) were chosen for PCR detection in this study. Among the four ARGs, sul1 and sul2 were present in all sampling sites while sul3 or sulA was absent in each sample. Similarly, sul1 and sul2 were also frequently found in other water environments including wastewater treatment plants ${ }^{[28]}$, aquaculture ponds ${ }^{[29]}$, and livestock lagoons ${ }^{[30]}$. High concentrations

Table 4. PCR results of ARGs and int1 gene in fecal coliforms

\begin{tabular}{|c|c|c|c|c|c|c|c|c|c|c|c|c|c|c|c|c|c|c|c|c|}
\hline \multirow{2}{*}{ Gene type } & \multicolumn{20}{|c|}{ No. of strains } \\
\hline & 1 & 2 & 3 & 4 & 5 & 6 & 7 & 8 & 9 & 10 & 11 & 12 & 13 & 14 & 15 & 16 & 17 & 18 & 19 & 20 \\
\hline int 1 & $-{ }^{\mathrm{b}}$ & - & - & - & - & - & + & + & - & - & - & - & - & - & - & - & - & - & - & - \\
\hline sul2 & - & - & - & - & - & - & - & - & - & - & - & - & - & - & - & - & - & - & - & - \\
\hline tet $C$ & $\mathrm{ND}^{\mathrm{c}}$ & ND & ND & ND & ND & ND & ND & ND & + & ND & ND & ND & ND & ND & ND & ND & ND & ND & ND & ND \\
\hline tet $G$ & ND & ND & ND & ND & ND & ND & ND & ND & - & ND & ND & ND & ND & ND & ND & ND & ND & ND & ND & ND \\
\hline bla $_{O X A-1}$ & ND & ND & ND & ND & ND & ND & ND & - & ND & - & ND & ND & ND & ND & ND & - & ND & ND & ND & - \\
\hline
\end{tabular}

\footnotetext{
${ }^{\mathrm{a}}+$ : PCR positive; ${ }^{\mathrm{b}}$-: PCR negative; ${ }^{\mathrm{c}}$ Not detected.
} 
of tetracycline and sulfanilamide have been detected in different types of aquaculture ponds around the Taihu Lake basin ${ }^{[31]}$ and the practice of aquaculture in Taihu Lake has reached $10647.02 \mathrm{hm}^{2}$ in $2003^{[32]}$. Therefore, massive use of tetracycline and sulfanilamide in aquaculture in Taihu Lake basin may play an important role in the wide distribution of tetracycline and sulfanilamide resistant genes.

Among the five kinds of $\beta$-lactam resistance genes (ampC, $b l a_{\mathrm{TEM}}, b l a_{\mathrm{SHV}}, b l a_{\mathrm{CTX}-\mathrm{M}}$, and $\left.b l a_{\mathrm{OXA}-1}\right)$ tested in this study, bla $a_{\text {OXA-1 }}$ was present in all water samples revealing the wide dissemination of $b l a_{\text {OXA-1 }}$ in Taihu Lake. However, other ARGs were absent in the water or sediment samples. Bla $a_{\mathrm{OXA}-1}$ has a broad host range including clinical isolates such as Klebsielia ${ }^{[33]}$, Salmonella $^{[34]}$, and Pseudomonadaceae ${ }^{[35]}$. On the other hand, this gene was seldom reported to be present in environmental samples. Chen et al. observed the absence of $b l a_{\mathrm{OXA}-1}$ in the waters of Yangtze River (Chongqing Basin $)^{[25]}$ but Zhang et al. recently reported high abundance of bla $a_{\text {OXA-1 }}$ in Jiulong River (Fujian Province, China) and the abundance was highly related to human activities ${ }^{[36]}$.

Among the tested integronase genes, results showed that only int 1 was present in all sampling locations in Taihu Lake while both int 2 and int 3 were undetected in each of the samples. Recently, int 1 had been detected in various water environments especially in wastewater treatment plants serving as a potential int 1 pool $^{[37]}$. The high population density in the region surrounding Taihu Lake may account for the wide dissemination of int1. Furthermore, int1 usually carries one or more gene cassettes, each of which containing one ARGs coding resistance to different antibiotics ${ }^{[38]}$. Thus, the int 1 gene cassettes found in Taihu Lake still require further investigation.

Antibiotic resistant fecal coliforms were already found widely disseminated in the environment ${ }^{[39]}$, even in drinking water in India ${ }^{[40]}$. As a very important drinking water source for the surrounding cities, Taihu Lake deserves more public health attention concerning fecal coliform contamination. Only 20 fecal coliforms were isolated from both water and sediment samples in this study which may be due to the low temperature during sampling time (water temperature around $10^{\circ} \mathrm{C}$ ). Low environmental temperature is unfavorable to the survival of fecal coliforms ${ }^{[41]}$. However, resistance to trimethoprim was found ubiquitous (95\%) among all the tested isolates. These results were in accordance with the high detection frequency of sul1 and sul2 genes in the water and sediment samples. However, genotype detection showed only $40 \%$ of fecal coliforms hosted sul1 gene. The reason may be due to the ability of many kinds of ARGs including dihydropteroate synthases genes sul and dihydrofolate reductase genes $d r f$ to code for trimethoprim resistance ${ }^{[42]}$. Similarly, the frequently detected $b l a_{\text {OXA-1 }}$ in the water samples was not present in ampicillin resistant strains. It is known that more than 400 kinds of $\beta$-lactam resistance genes have been discovered ${ }^{[9]}$, so a more comprehensive investigation has to be conducted to determine the occurrence of different ARGs in bacterial isolates.

In conclusion, this study provided baseline information about the occurrence of ARGs in Taihu Lake. TetC, tetG, sul1, sul2, and bla $a_{\mathrm{OXA}-1}$ are widely distributed in Taihu Lake and the abundance of ARGs in the northern and western parts of the lake are relatively higher than the other parts. Nearly all fecal bacterial coliforms isolated were found to be resistant to trimethoprim and multi-antimicrobial resistance isolates were also observed which deserve special attention. Int 1 is ubiquitous in Taihu Lake and future work should include identification of the ARGs contained in its gene cassettes. More comprehensive and in-depth studies have to be conducted to determine the occurrence, abundance, and diversity of the ARGs as well as the temporal and spatial variations and its relationship with environmental conditions in Taihu Lake.

\section{Conflict of Interest and Funding}

No conflict of interest was reported by the authors. This study was financially supported by the Major Science and Technology Program of China for Water Pollution Control and Treatment (2012ZX07101-002004 and 2012ZX07506-004-004) and Environmental Protection Research Project of Jiangsu Province, China (2012044 and 2012045).

\section{Acknowledgements}

The authors would like to thank Messrs. ZQ Xu, KL Huang, FZ Zhao, JB Yin and P Shi for their kind help in the research.

\section{References}

1. Zhang X X, Wu B, Zhang Y, et al. 2009, Class 1 integronase gene and tetracycline resistance genes tetA 
and tet $\mathrm{C}$ in different water environments of Jiangsu Province, China. Ecotoxicology, vol.18(6): 652-660. http://dx.doi.org/10.1007/s10646-009-0332-3.

2. Zhang X X, Zhang T and Fang H P, 2009, Antibiotic resistance genes in water environment. Applied Microbiology and Biotechnology, vol.82(3): 397-414. http://dx.doi.org/10.1007/s00253-008-1829-z.

3. Koonin E V, Makarova K S and Aravind L, 2001, Horizontal gene transfer in prokaryotes: quantification and classification. Annual Review of Microbiology, vol.55: 709-742.

http://dx.doi.org/10.1146/annurev.micro.55.1.709.

4. Ding C and He J, 2010, Effect of antibiotics in the environment on microbial populations. Applied Microbiology and Biotechnology, vol.87(3): 925-941. http://dx.doi.org/10.1007/s00253-010-2649-5.

5. Martinez J L, 2009, Environmental pollution by antibiotics and by antibiotic resistance determinants. Environmental Pollution, vol.157(11): 2893-2902. http://dx.doi.org/10.1016/j.envpol.2009.05.051.

6. Kemper N, 2008, Veterinary antibiotics in the aquatic and terrestrial environment. Ecological Indicators, vol.8(1): 1-13.

http://dx.doi.org/10.1016/j.ecolind.2007.06.002.

7. Roberts M C, 2005, Update on acquired tetracycline resistance genes. FEMS Microbiology Letters, vol.245(2): 195-203.

http://dx.doi.org/10.1016/j.femsle.2005.02.034.

8. Kehrenberg C and Schwarz S, 2005, dfrA20, a novel trimethoprim resistance gene from Pasteurella multocida. Antimicrobial Agents and Chemotherapy, vol.49(1): 414-417.

http://dx.doi.org/10.1128/AAC.49.1.414-417.2005.

9. Li X-Z, Mehrotra M, Ghimire S, et al. 2007, $\beta$-Lactam resistance and $\beta$-lactamases in bacteria of animal origin. Veterinary Microbiology, vol.121(3-4): 197-214. http://dx.doi.org/10.1016/j.vetmic.2007.01.015.

10. Nield B S, Holmes A J, Gillings M R, et al. 2001, Recovery of new integron classes from environmental DNA. FEMS Microbiology Letters, vol.195(1): 59-65. http://dx.doi.org/10.1111/j.1574-6968.2001.tb10498.x.

11. White P A, McIver C J and Rawlinson W D, 2001, Integrons and gene cassettes in the enterobacteriaceae. Antimicrobial Agents and Chemotherapy, vol.45(9): 2658- 2661. http://dx.doi.org/10.1128/AAC.45.9.2658-2661.2001.

12. Shen P P, Shi Q, Hua Z C, et al. 2003, Analysis of microcystins in cyanobacteria blooms and surface water samples from Meiliang Bay, Taihu Lake, China. Environment International, vol.29(5): 641-647. http://dx.doi.org/10.1016/S0160-4120(03)00047-3.
13. Wang H, Wang C, Wu W, et al. 2003, Persistent organic pollutants in water and surface sediments of Taihu Lake, China and risk assessment. Chemosphere, vol.50(4): 557-562. http://dx.doi.org/10.1016/S0045-6535(02)00484-8.

14. Qu W, Dickman M and Wang S, 2001, Multivariate analysis of heavy metal and nutrient concentrations in sediments of Taihu Lake, China. Hydrobiologia, vol.450(1): 83-89. http://dx.doi.org/10.1023/A:1017551701587.

15. Wang X, Lu Y, Han J, et al. 2007, Identification of anthropogenic influences on water quality of rivers in Taihu watershed. Journal of Environmental Sciences, vol.19(4): 475-481. http://dx.doi.org/10.1016/S1001-0742(07)60080-1.

16. Sayah R S, Kaneene J B, Johnson Y, et al. 2005, Patterns of antimicrobial resistance observed in escherichia coli isolates obtained from domestic- and wild-animal fecal samples, human septage, and surface water. Applied and Environmental Microbiology, vol.71(3): 1394 1404.

http://dx.doi.org/10.1128/AEM.71.3.1394-1404.2005.

17. Schmidt A S, Bruun M S, Dalsgaard I, et al. 2000, Occurrence of antimicrobial resistance in fish-pathogenic and environmental bacteria associated with four danish rainbow trout farms. Applied and Environmental Microbiology, vol.66(11): 4908-4915.

http://dx.doi.org/10.1128/AEM.66.11.4908-4915.2000.

18. Han N N, Zhang S H, Wang P F, et al. 2013, Characterization of antibiotic resistance $E$. coli and antibiotic resistance genes in aquatic environment of Taihu Lake, China. Applied Mechanics and Materials, vol.295-298: 630-634.

http://dx.doi.org/10.4028/www.scientific.net/AMM.295298.630.

19. Niemi M, Sibakov M and Niemela S, 1983, Antibiotic resistance among different species of fecal coliforms isolated from water samples. Applied and Environmental Microbiology, vol.45(1): 79-83.

20. Gueimonde M, Tölkkö S, Korpimäki T, et al. 2004, New real-time quantitative pcr procedure for quantification of bifidobacteria in human fecal samples. Applied and Environmental Microbiology, vol.70(7):, 4165-4169. http://dx.doi.org/10.1128/AEM.70.7.4165-4169.2004.

21. Sandalli C, Özgümüş O B and Sevim A, 2010, Characterization of tetracycline resistance genes in tetracycline- resistant Enterobacteriaceae obtained from a coliform collection. World Journal of Microbiology and Biotechnology, vol.26(11): 2099-2103. http://dx.doi.org/10.1007/s11274-010-0381-z.

22. Tao R, Ying G G, Su H C, et al. 2010, Detection of 
antibiotic resistance and tetracycline resistance genes in Enterobacteriaceae isolated from the Pearl rivers in South China. Environmental Pollution, vol.158(6): 21012109.

http://dx.doi.org/10.1016/j.envpol.2010.03.004.

23. Gao P, Mao D, Luo Y, et al. 2012, Occurrence of sulfonamide and tetracycline-resistant bacteria and resistance genes in aquaculture environment. Water Research, vol.46(7): 2355-2364.

http://dx.doi.org/10.1016/j.watres.2012.02.004.

24. Zou S, Zhu C, He Z, et al. 2009, Preliminary studies on the pollution levels of antibiotic resistance genes in the water of Beijiang River, South China. Asian Journal of Ecotoxicology, vol.4: 655-660.

25. Chen H, Shu W, Chang X, et al. 2010, The profile of antibiotics resistance and integrons of extended-spectrum beta-lactamase producing thermotolerant coliforms isolated from the Yangtze River basin in Chongqing. Environmental Pollution, vol.158(7): 2459-2464. http://dx.doi.org/10.1016/j.envpol.2010.03.023.

26. Feng L, 2010, The presence of antibiotic resistance genes in typical region of Tianjin and the environmental behavior of DNA. Nankai University.

27. Wang C, Lu G, Peifang W, et al. 2011, Assessment of environmental pollution of Taihu Lake by combining active biomonitoring and integrated biomarker response. Environmental Science and Technology, vol.45(8): 3746-3752.

http://dx.doi.org/10.1021/es1037047.

28. Phuong Hoa P T, Nonaka L, Hung Viet P, et al. 2008, Detection of the sul1, sul2, and sul3 genes in sulfonamide-resistant bacteria from wastewater and shrimp ponds of north Vietnam. Science of the Total Environment, vol.405(1-3): 377-384.

http://dx.doi.org/10.1016/j.scitotenv.2008.06.023.

29. Ji X, Liu F, Shen Q, et al. 2011, Quantitative detection of sulfonamides and tetracycline antibiotics and resistance genes in sewage farms. Ecology and Environmental Science, 2011-05: 927-933.

30. McKinney C W, Loftin K A, Meyer M T, et al. 2010, tet and sul antibiotic resistance genes in livestock lagoons of various operation type, configuration, and antibiotic occurrence. Environmental Science and Technology, vol.44(16): 6102-6109. http://dx.doi.org/10.1021/es9038165.

31. Jiang L, Chen S, Yang R, et al. 2008, Occurrence of antibiotics in the aquatic environment of the Changjiang Delta, China. Environmental Chemistry, vol.27: 371-374.

32. Yang Y, Jiang N, Yin L, et al. 2005, RS-based dynamic monitoring of lake area and enclosure culture in east Taihu Lake. Journal of Lake Science, vol.17: 927-933.
33. Ruiz E, Rezusta A, Saenz Y, et al. 2011, New genetic environments of aac(6')-Ib-cr gene in a multiresistant Klebsiella oxytoca strain causing an outbreak in a pediatric intensive care unit. Diagnostic Microbiolgy and Infectious Disease, vol.69(2): 236-238. http://dx.doi.org/10.1016/j.diagmicrobio.2010.09.004.

34. Lee K, Yong D, Yum J H, et al. 2003, Diversity of TEM-52 extended-spectrum $\beta$-lactamase-producing nontyphoidal Salmonella isolates in Korea. Journal of Antimicrobial Chemotherapy, vol.52(3): 493-496. http://dx.doi.org/10.1093/jac/dkg385.

35. Ryoo N H, Lee K, Lim J B, et al. 2009, Outbreak by meropenem-resistant Pseudomonas aeruginosa producing IMP-6 metallo- $\beta$-lactamase in a Korean hospital. Diagnostic Microbiology and Infectious Disease, vol.63(1): 115-117. http://dx.doi.org/10.1016/j.diagmicrobio.2008.08.019.

36. Zhang S T, Lv L, Zhang Y, et al. 2013, Occurrence and variations of five classes of antibiotic resistance genes along the Jiulong River in southeast China. Journal of Environmental Biology, vol.34(2 Spec No): 345-351.

37. Tennstedt T, Szczepanowski R, Braun S, et al. 2003, Occurrence of integron-associated resistance gene cassettes located on antibiotic resistance plasmids isolated from a wastewater treatment plant. FEMS Microbiololgy Ecology, vol.45(3): 239-252. http://dx.doi.org/10.1016/S0168-6496(03)00164-8.

38. Fluit A C and Schmitz F J, 1999, Class 1 integrons, gene cassettes, mobility, and epidemiology. European Journal of Clinical Microbiology and Infectious Diseases, vol.18(11): 761-770. http://dx.doi.org/10.1007/s100960050398.

39. da Silva T F B X, Ramos D T, Dziedzic M, et al. 2011, Microbiological quality and antibiotic resistance analysis of a Brazilian water supply source. Water, Air, and Soil Pollution, vol.218(1): 611-618. http://dx.doi.org/10.1007/s11270-010-0672-x.

40. Pathak S P and Gopal K, 2008, Prevalence of bacterial contamination with antibiotic resistant and enterotoxigenic fecal coliforms in treated drinking water. Journal of Toxicology and Environmental Health, Part A: Current Issues, vol.71(7): 427-433. http://dx.doi.org/10.1080/15287390701838796.

41. Howell J M, Coyne M S and Cornelius P L, 2008, Effect of sediment particle size and temperature on fecal bacteria mortality rates and the fecal coliform/fecal streptococci ratio. Journal of Environmental Quality, vol.25(6): 1216- 1220.

http://dx.doi.org/10.2134/jeq1996.00472425002500060 007x.

42. Sköld O, 2001, Resistance to trimethoprim and sulfona- 
mides. Veterinary Research, vol.32(3-4): 261-273. http://dx.doi.org/10.1051/vetres:2001123.

43. Ng L K, Martin I, Alfa M, et al. 2001, Multiplex PCR for the detection of tetracycline resistant genes. Molecular and Cellular Probes, vol.15(4): 209-215. http://dx.doi.org/10.1006/mcpr.2001.0363.

44. Kerrn M B, Klemmensen T, Frimodt-Møller N, et al. 2002, Susceptibility of Danish Escherichia coli strains isolated from urinary tract infections and bacteraemia, and distribution of sul genes conferring sulphonamide resistance. Journal of Antimicrobial Chemotherapy, vol.50(4): 513-516. http://dx.doi.org/10.1093/jac/dkf164.

45. Pei R, Kim S-C, Carlson K H, et al. 2006, Effect of river landscape on the sediment concentrations of antibiotics and corresponding antibiotic resistance genes (ARG). Water Research, vol.40(12): 2427-2435. http://dx.doi.org/10.1016/j.watres.2006.04.017.

46. Szczepanowski R, Linke B, Krahn I, et al. 2009, Detection of 140 clinically relevant antibiotic-resistance genes in the plasmid metagenome of wastewater treatment plant bacteria showing reduced susceptibility to selected antibiotics. Microbiology, vol.155: 2306-2319. http://dx.doi.org/10.1099/mic.0.028233-0. 